RESEARCH

\title{
Primary hyperparathyroidism as first manifestation in multiple endocrine neoplasia type 2A: an international multicenter study
}

Louise Vølund Larsen ${ }^{1}$, Delphine Mirebeau-Prunier ${ }^{2}$. Tsuneo Imai ${ }^{3}$ Cristina Alvarez-Escola ${ }^{4}$ Kornelia Hasse-Laza Simona Censi ${ }^{6}$, Luciana A Castroneves ${ }^{7}$, Akihiro Sakurai ${ }^{8}$, Minoru Kihara ${ }^{9}$, Kiyomi Horiuchi ${ }^{10}$, Véronique Dorine Barbu'11,12, Francoise Borson-Chazot 12,13, Anne-Paule Gimenez-Roqueplo ${ }^{12,14,15}$, Pascal Pigny ${ }^{12,16}$, Stephane Pinson ${ }^{12,17}$, Nelson Wohllk ${ }^{18}$, Charis Eng ${ }^{19}$, Berna Imge Aydogan ${ }^{20}$, Dhananjaya Saranath ${ }^{21}$, Sarka Dvorakova ${ }^{22}$, Frederic Castinetti ${ }^{23,24}$, Attila Patocs ${ }^{25}$, Damijan Bergant ${ }^{26}$, Thera P Links ${ }^{27}$, Mariola Peczkowskaa ${ }^{28}$, Ana 0 Hoff $^{7}$, Caterina Mian ${ }^{6}$, Trisha Dwight ${ }^{29}$, Barbara Jarzab ${ }^{30}$, Hartmut P H Neumann ${ }^{31}$, Mercedes Robledo ${ }^{32,33}$, Shinya Uchino ${ }^{34}$, Anne Barlier ${ }^{12,35}$, Christian Godballe ${ }^{1}$ and Jes Sloth Mathiesen (10,36

'Department of ORL Head \& Neck Surgery and Audiology, Odense University Hospital, Odense, Denmark 2Laboratoire de Biochimie et Biologie Moléculaire, CHU Angers, Université d'Angers, UMR CNRS 6015, INSERM U1083, MITOVASC, Angers, France ${ }^{3}$ Department of Breast \& Endocrine Surgery, National Hospital Organization, Higashinagoya National Hospital, Nagoya, Japan ${ }^{4}$ Endocrinology and Nutrition Department, University Hospital 'La Paz', Madrid, Spain

${ }^{5}$ Department of Nuclear Medicine and Endocrine Oncology, Maria Sklodowska-Curie National Research Institute of Oncology, Gliwice Branch, Gliwice, Poland

${ }^{6}$ Endocrinology Unit, Department of Medicine (DIMED), University of Padua, Padua, Italy

${ }^{7}$ Department of Endocrinology, Endocrine Oncology Unit, Instituto do Cancer do Estado de São Paulo, Faculdade de Medicina da Universidade de São Paulo, São Paulo, Brazil

${ }^{8}$ Department of Medical Genetics and Genomics, Sapporo Medical University School of Medicine, Sapporo, Japan

${ }^{9}$ Department of Surgery, Kuma Hospital, Kobe, Hyogo, Japan

${ }^{10}$ Department of Breast and Endocrine Surgery, Tokyo Women's Medical University, Tokyo, Japan

${ }^{11} \mathrm{AP}-\mathrm{HP}$, Sorbonne Université, Laboratoire Commun de Biologie et Génétique Moléculaires, Hôpital St Antoine \& INSERM CRSA, Paris, France

${ }^{12}$ Réseau TenGen, Marseille, France

${ }^{13}$ Fédération d'Endocrinologie, Hospices Civils de Lyon, Université Lyon 1, France

${ }^{14}$ Service de Génétique, AP-HP, Hôpital européen Georges Pompidou, Paris, France

${ }^{15}$ Université de Paris, PARCC, INSERM, Paris, France

${ }^{16}$ Laboratoire de Biochimie et Oncologie Moléculaire, CHU Lille, Lille, France

${ }^{17}$ Laboratoire de Génétique Moléculaire, CHU Lyon, Lyon, France

${ }^{18}$ Endocrine Section, Hospital del Salvador, Santiago de Chile, Department of Medicine, University of Chile, Santiago, Chile

${ }^{19} \mathrm{Genomic}$ Medicine Institute, Lerner Research Institute and Taussig Cancer Institute, Cleveland Clinic, Cleveland, Ohio, USA

${ }^{20}$ Department of Endocrinology And Metabolic Diseases, Ankara University School of Medicine, Ankara, Turkey

${ }^{21}$ Department of Research Studies \& Additional Projects, Cancer Patients Aid Association, Dr. Vithaldas Parmar Research \& Medical Centre, Worli, Mumbai, India

${ }^{22}$ Department of Molecular Endocrinology, Institute of Endocrinology, Prague, Czech Republic

${ }^{23}$ Aix-Marseille Université, Institut National de la Santé et de la Recherche Médicale (INSERM), U1251, Marseille Medical Genetics (MMG), Marseille, France ${ }^{24}$ Department of Endocrinology, Assistance Publique-Hôpitaux de Marseille (AP-HM), Hôpital de la Conception, Centre de Référence des Maladies Rares de l'hypophyse HYPO, Marseille, France

${ }^{25}$ HAS-SE Momentum Hereditary Endocrine Tumors Research Group, Semmelweis University, Budapest, Hungary

${ }^{26}$ Department of Surgical Oncology, Institute of Oncology, Ljubljana, Slovenia

${ }^{27}$ Department of Endocrinology, University of Groningen, University Medical Center Groningen, Groningen, Netherlands

${ }^{28}$ Department of Hypertension, Institute of Cardiology, Warsaw, Poland

${ }^{29}$ Cancer Genetics, Kolling Institute, Royal North Shore Hospital and University of Sydney, Sydney, New South Wales, Australia

${ }^{30}$ Department of Nuclear Medicine and Endocrine Oncology, Maria Sklodowska-Curie National Research Institute of Oncology, Gliwice Branch, Gliwice, Poland

${ }^{31}$ Section for Preventive Medicine, Medical Center-University of Freiburg, Faculty of Medicine, Albert Ludwigs-University of Freiburg, Freiburg, Germany

${ }^{32}$ Hereditary Endocrine Cancer Group, Spanish National Cancer Research Center (CNIO), Madrid, Spain

${ }^{33}$ Centro de Investigación Biomédica en Red de Enfermedades Raras (CIBERER), Madrid, Spain

${ }^{34}$ Department of Endocrine Surgery, Noguchi Thyroid Clinic and Hospital Foundation, Beppu, Oita, Japan

${ }^{35}$ Aix Marseille Univ, APHM, INSERM, MMG, Laboratory of Molecular Biology, Hospital La Conception, Marseille, France

${ }^{36}$ Department of Clinical Research, University of Southern Denmark, Odense, Denmark

Correspondence should be addressed to J S Mathiesen: jes_mathiesen@yahoo.dk

https://ec.bioscientifica.com

https://doi.org/10.1530/EC-20-0163 (c) 2020 The authors Published by Bioscientifica Ltd

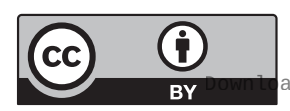

This work is licensed under a Creative Commons Attribution 4.0 International License. ded from Bioscientifica.com at $04 / 26 / 2023$ 12:15:04PM 
Abstract

Objective: Multiple endocrine neoplasia type 2A (MEN 2A) is a rare syndrome caused by $R E T$ germline mutations and has been associated with primary hyperparathyroidism (PHPT) in up to $30 \%$ of cases. Recommendations on RET screening in patients with apparently sporadic PHPT are unclear. We aimed to estimate the prevalence of cases presenting with PHPT as first manifestation among MEN 2A index cases and to characterize the former cases.

Design and methods: An international retrospective multicenter study of 1085 MEN 2A index cases. Experts from MEN 2 centers all over the world were invited to participate. A total of 19 centers in 17 different countries provided registry data of index cases followed from 1974 to 2017.

Results: Ten cases presented with PHPT as their first manifestation of MEN 2A, yielding a prevalence of $0.9 \%$ (95\% Cl: 0.4-1.6). 9/10 cases were diagnosed with medullary thyroid carcinoma (MTC) in relation to parathyroid surgery and $1 / 10$ was diagnosed 15 years after parathyroid surgery. $7 / 9$ cases with full TNM data were node-positive at MTC diagnosis.

Conclusions: Our data suggest that the prevalence of MEN 2A index cases that present with PHPT as their first manifestation is very low. The majority of index cases presenting with PHPT as first manifestation have synchronous MTC and are often node-positive. Thus, our observations suggest that not performing RET mutation analysis in patients with apparently sporadic PHPT would result in an extremely low false-negative rate, if no other MEN 2A component, specifically MTC, are found during work-up or resection of PHPT.

\section{Introduction}

Multiple endocrine neoplasia type 2 (MEN 2) is an autosomal dominant inherited cancer syndrome caused by germline mutations of the rearranged during transfection (RET) proto-oncogene $(1,2,3,4,5,6)$. The syndrome is divided into MEN 2A and MEN 2B with a point prevalence of $13-24$ per million and 1-2 per million, respectively $(7,8,9,10)$. Virtually all patients with MEN 2A develop medullary thyroid carcinoma (MTC), while lower numbers develop pheochromocytoma, primary hyperparathyroidism (PHPT), cutaneous lichen amyloidosis (CLA) and Hirschsprung disease (HSCR) (11).

For identification of new MEN 2A index cases and families, RET screening has been recommended for years in all patients with apparently sporadic MTC, pheochromocytoma, CLA and infants with $\operatorname{HSCR}(11,12$, 13, 14). However, for patients with apparently sporadic PHPT, recommendations on RET screening are less clear. Thus, in 2001 the consensus guidelines from the seventh international workshop on MEN recommended against RET screening in these patients (13), while the issue lacks mentioning in the 2009 and 2015 guidelines by the American Thyroid Association $(11,12)$.

To ascertain if all patients with apparently sporadic PHPT should be RET screened, a valuable estimate would be the prevalence of MEN 2A index cases presenting with PHPT as first manifestation in an unselected populationbased cohort of apparently sporadic PHPT cases, who have all been RET screened. To our knowledge, however, no such cohorts exist. Instead, a surrogate cohort study is to examine the prevalence of MEN 2A index cases presenting with PHPT as the first manifestation in an unselected cohort of MEN 2A index cases. Based on the experience from previous MEN 2A PHPT series $(15,16)$, we hypothesized that this prevalence would be low.

Consequently, we aimed to estimate the prevalence of MEN 2A index cases presenting with PHPT as first manifestation in an unselected cohort of MEN 2A index cases. Additionally, we aimed to characterize the cases presenting with PHPT as their first manifestation.

\section{Methods}

\section{Study design and participants}

This investigation is an international retrospective multicenter study of 1085 MEN 2A index cases. We invited experts from 40 MEN 2 centers all over the world to participate. This yielded a total of 19 centers in

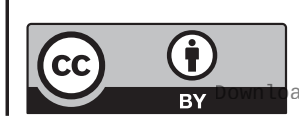

This work is licensed under a Creative Commons Attribution 4.0 International License. ded from Bioscientifica.com at 04/26/2023 12:15:04PM 
17 different countries, including Denmark, providing data of index cases followed from 1974 to 2017 (Supplementary Table 1, see section on supplementary materials given at the end of this article). Data were retrieved from June 2017 to September 2019.

\section{Data sources}

Data were drawn from the registry of each center. Some of the patients have been reported on previous occasions and updated data were obtained $(17,18,19,20,21,22$, $23,24,25,26)$.

\section{Variables}

Patients were defined as having MEN 2 if they had tested positive for a RET germline sequence change classified as pathogenic (mutation) in the ARUP MEN 2 database on February 1, 2020 (27). For inclusion of only the MEN 2A patients, we excluded those with mutations pathognomonic of MEN 2B (RET M918T and A883F) (28, 29). An index case was defined as a clinically affected individual through whom attention is first drawn to MEN $2 \mathrm{~A}$ in a family (https://www.cancer.gov/publications/ dictionaries/genetics-dictionary/def/index-case). The first manifestation in MEN 2A was defined by the symptoms or biochemistry leading to initial endocrine work-up and was judged by the MEN 2 experts participating in the study. PHPT had to be both biochemically (hypercalcemia and an elevated or inappropriately normal parathyroid hormone level (30)) and histologically proven, while MTC, pheochromocytoma, CLA and HSCR were considered by histology only. TNM staging was performed according to the seventh edition of the American Joint Committee on Cancer Staging Manual (31). Biochemical cure was regarded as undetectable basal calcitonin at last biochemical follow-up.

\section{Statistical analysis}

Continuous data were presented as median and range. All analyses were done using Stata ${ }^{\circledR} 15.1$ (StataCorp LP).

\section{Ethics}

Informed consent was given by all patients participating in the study for RET screening. Ethical approval was obtained from the institutional review boards of all participating centers when required: French National Commission for Computerized Data and Individual
Freedom, Institutional Ethical Review Board of Shinshu University School of Medicine (Matsumoto, Japan), Comité de bioética y bienestar animal of the Instituto de Salud Carlos III, Northern Sydney Local Health District Human Research Ethics Committee, ICESP/HCFMUSP, Ethics Committee of the Institute of Cardiology (Warsaw, Poland), Regional Committee on Health Research Ethics for Southern Denmark, Scientific and Research Committee of the Medical Research Council of Hungary, Ethics Committee of Aix Marseille University, Ethics Committee of the Institute of Endocrinology (Prague, Czech Republic), Ethics Committee of Reliance Life Sciences (Navi Mumbai, India), Local Ethics Committee of Ankara University Faculty of Medicine, Cleveland Clinic Institutional Review Board for Human Subjects Protection and Ethical Committee (Santiago, Chile). This was in accordance with the ethical standards of each country and center.

The investigation was approved by the respective institutional review boards for human subjects protection in accordance with the ethical standards of each country and center.

\section{Results}

A total of 1085 MEN 2A index cases were included in the study. The distribution of RET germline mutations in these cases is shown in Table 1. The most frequent site of mutations was exon 11 (53\%), followed by exon 10 (25\%), exon $14(12 \%)$, exon 13 (7\%), exon 15 (3\%), exon 8 (1\%) and exon $16(0 \%)$. Of the 1085 cases, 10 had presented with PHPT as first manifestation of the syndrome, yielding a prevalence of $0.9 \%$ (95\% CI: $0.4-1.6)$.

Characteristics of the ten cases are depicted in Table 2. In these cases, the female-to-male ratio was $4.0(95 \%$ CI: -2.2-10.2), while the median age at diagnosis of PHPT was 34.5 years (range, 14-68). All cases were diagnosed with PHPT between 1993 and 2012. Of these, seven were diagnosed in the new millennium.

All cases with pertinent data $(n=9)$ were symptomatic at diagnosis of PHPT with symptoms being nephrolithiasis $(n=8)$ and polyuria $(n=1)$. MTC was diagnosed in $10 / 10$ cases. 9/10 were diagnosed in relation to parathyroid surgery as a synchronous MTC and 1/10 was diagnosed 15 years after parathyroid surgery, as a metachronous MTC. In three cases, MTC was not suspected during preoperative PHPT work-up, but diagnosed during parathyroid surgery. $7 / 9$ cases with full TNM data available had regional lymph node metastases at time of

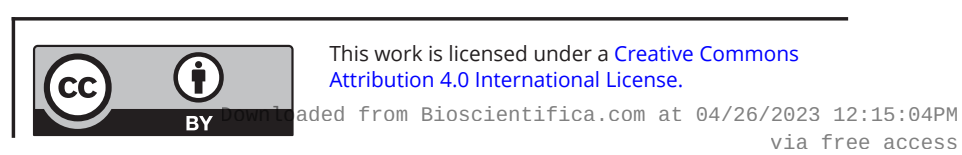


Table 1 Distributions of RET mutations among 1085 MEN 2A index cases.

\begin{tabular}{|c|c|c|}
\hline RET mutation & $n$ & $(\%)$ \\
\hline \multicolumn{3}{|l|}{ Exon 8} \\
\hline C531R & 3 & (0) \\
\hline G533C & 5 & (0) \\
\hline G548S & 2 & (0) \\
\hline \multicolumn{3}{|l|}{ Exon 10} \\
\hline C609F/G/R/S/Y & 19 & (2) \\
\hline C611F/G/W/Y & 48 & (4) \\
\hline C618F/G/R/S/W/Y & 113 & (10) \\
\hline C620F/G/R/S/W/Y & 87 & (8) \\
\hline \multicolumn{3}{|l|}{ Exon 11} \\
\hline $\mathrm{C} 630 \mathrm{R} / \mathrm{Y}$ & 4 & (0) \\
\hline D631Y & 3 & (0) \\
\hline C634F/G/L/S/R/W/Y & 562 & (52) \\
\hline $\mathrm{K} 666 \mathrm{E} / \mathrm{N} / \mathrm{T}$ & 6 & (1) \\
\hline \multicolumn{3}{|l|}{ Exon 13} \\
\hline E768D & 18 & (2) \\
\hline Q781R & 1 & (0) \\
\hline L790F & 52 & (5) \\
\hline \multicolumn{3}{|l|}{ Exon 14} \\
\hline V804L/M & 132 & $(12)$ \\
\hline \multicolumn{3}{|l|}{ Exon 15} \\
\hline S891A & 28 & (3) \\
\hline \multicolumn{3}{|l|}{ Exon 16} \\
\hline R912P & 1 & (0) \\
\hline M918V & 1 & (0) \\
\hline Total & 1085 & (100) \\
\hline
\end{tabular}

Due to rounding up, not all sums of the numbers fit. MEN 2A, multiple endocrine neoplasia type 2A; RET, rearranged during transfection.

MTC diagnosis. Biochemical cure was achieved only in the node-negative cases $(n=2)$.

\section{Discussion}

This large international retrospective multicenter study found that $0.9 \%$ of cases had PHPT as their first manifestation of MEN 2A. In the cases presenting with PHPT as first manifestation, MTC was coexistent and had metastasized to regional lymph nodes in 7/9 cases.

\section{Prevalence}

In this study, we found $0.9 \%$ of our MEN $2 \mathrm{~A}$ index cases presented with PHPT as the first manifestation of the syndrome. To our knowledge, no similar studies on MEN $2 \mathrm{~A}$ index cases have been reported, rendering comparisons difficult. However, there exist several studies, in which the study cohorts comprise only MEN 2A cases with PHPT. In these cohorts the prevalence of MEN 2A cases presenting with PHPT as a first manifestation ranges $0-11 \%$
$(15,16,32,33,34,35)$. Considering the selection of these cohorts and the fact that they included index and non-index cases, presumably a majority of the latter, our prevalence of $0.9 \%$ appears as a solid estimate. This is in line with the experience of other smaller series, that PHPT rarely was the first diagnosed manifestation $(16,36)$. In fact, there seems to be a decrease in the overall prevalence of PHPT in MEN 2A cohorts reported over time, possibly explained by inclusion of more patients with the fullblown syndrome (MTC, pheochromocytoma and PHPT) in the earliest series $(6,33,37)$.

In our overall cohort, the most frequently mutated codon was 634, followed by codons 804, 618, 620, 790, $611,891,609,768$ and other rarely mutated codons. With only minor differences, likely accounted for by founder effects, the distribution of mutations in our cohort is, by and large, comparable to that of series in the literature ( 7 , $17,19,20,21,38,39,40,41,42,43,44,45)$.

\section{Characteristics of cases}

Our study depicts the characteristics of MEN 2A index cases presenting with PHPT as first manifestation. Age at diagnosis is by and large similar to that of other MEN 2A PHPT cohorts $(15,16,32,33,35,46)$. Our female-tomale ratio of 4.0 is higher than that (1.3-1.9) reported by others $(15,16,32,34)$. This may be a question of sample size, but may also indicate that female MEN 2A cases in comparison to males are more prone to present with PHPT as first manifestation.

In our cohort all cases with pertinent data were symptomatic at diagnosis of PHPT. This is in contrast with other MEN 2A PHPT cohorts, in which most cases (58-84\%) are asymptomatic $(15,16,32,33,34)$. A likely explanation is the difference in cohorts, where our cohort solely comprises index cases presenting with PHPT as first manifestation, while the other cohorts presumably comprise mainly non-index cases diagnosed with PHPT by screening before they become symptomatic.

Nine of our ten cases were diagnosed with MTC, either due to a suspected or unsuspected finding in relation to parathyroid surgery. As a consequence, RET screening would be prompted by the MTC, if not instigated by the PHPT diagnosis. To our knowledge, the MTC TNM stage of the cases has not previously been reported in MEN 2A PHPT cohorts. In our cohort, 7/9 cases with available data were MTC node positive. This may reflect an overrepresentation of codon 634 mutation carriers (6/10), who generally have earlier age at MTC onset compared with other MEN 2A patients $(47,48)$. The over-representation

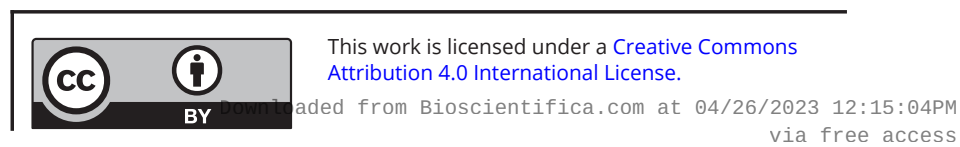




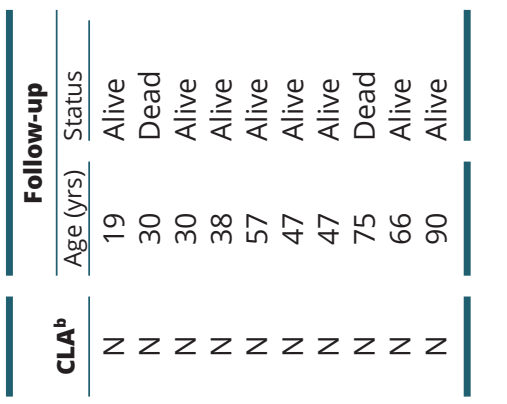

岕 $|z z z z z z z z z|$
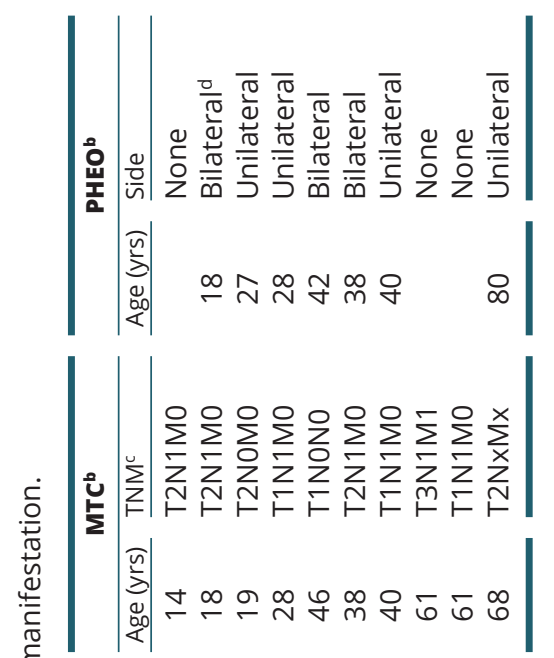

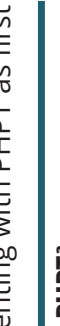

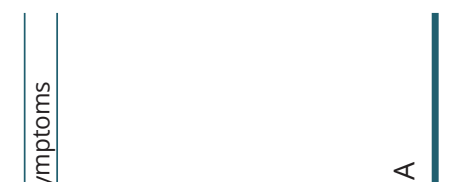

जी $>>>>>>>>\mathbb{Z}$
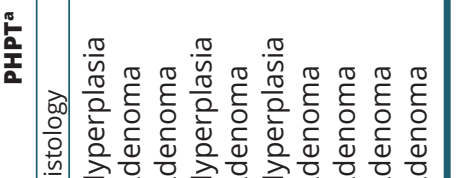

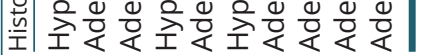

जิ $\forall \stackrel{\infty}{\sim} \stackrel{\infty}{\sim} \bar{m} \stackrel{\infty}{m}$ q $\bar{\sigma} \underset{0}{\infty}$
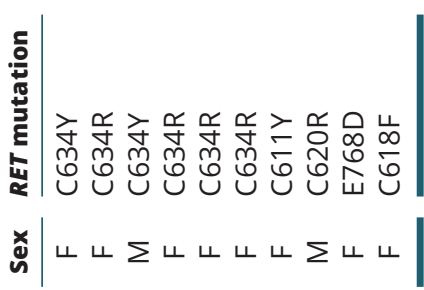

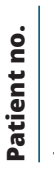

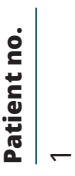

in this cohort of MEN2A index cases presenting with PHPT as first manifestation is expected, as carriers of codon 634 mutations are regarded as having the highest penetrance of PHPT $(6,46)$. Given the fact, that longterm biochemical cure only rarely occurs in node-positive MTC (49), the likelihood of cure as indicated by our cohort is supposedly very low for MEN 2A index cases that present with PHPT as their first manifestation. Due to the high prevalence of regional lymph node metastases in these cases, neck dissection is often warranted already at primary surgery for better local control. Although controversial, the preoperative serum calcitonin level may also guide this decision, despite the fact that high levels not always guarantee metastases $(50,51,52)$. On a general comment, the cohort of cases presenting with PHPT as first manifestation is small making generalizations difficult.

\section{Limitations}

To assess if all cases with apparently sporadic PHPT should be RET screened, one could have estimated the prevalence of MEN 2A index cases presenting with PHPT as first manifestation in an unselected population-based cohort of cases with apparently sporadic PHPT, in which all had been RET screened. To our knowledge, no such cohorts exist, rendering such a study unfeasible. Instead, we sought to estimate the prevalence of MEN 2A index cases presenting with PHPT as their first manifestation in the largest series of MEN 2A index cases seen to date.

An issue that may underestimate the prevalence is the fact that our study cohort consists of already recognized MEN 2A index cases. Thus, we cannot rule out that some MEN 2A index cases presenting with PHPT as first manifestation, are still unrecognized as MEN 2A cases, if they have not been RET screened and instead are still regarded as sporadic PHPT cases. To comply with this, a study cohort of apparently sporadic PHPT cases is needed as previously described. However, as the first RET germline mutations causing MEN 2A were discovered $>25$ years ago $(1,2)$ combined with the fact that de novo mutations rarely occur (53), one may argue that the pool of unrecognized MEN 2A families arising from de novo mutations likely is very small, thus minimizing the issue.

As in several other multicenter studies on MEN 2, selection bias in the current study cannot be ruled out $(6,15,28,29,54,55,56,57,58,59,60,61,62,63)$. Including all MEN 2 centers in the world is an immensely difficult and time-consuming task. However, formation of a consortium including all MEN 2 centers worldwide may be helpful for future studies. 
A limitation of the study is the lack of preoperative data, especially regarding ultrasonography and serum calcitonin. This hinders the elaborations on reasons for the preoperative suspicion of MTC during PHPT work-up and makes it difficult to assess potential diagnostic bias. High-resolution ultrasonography is routinely used in the preoperative setup for PHPT patients, while measurements of serum calcitonin are not (64). In some patients the preoperative serum calcitonin will likely be measured as a consequence of thyroid nodules found by ultrasonography $(65,66,67,68,69)$. Some authors have suggested systematically preoperative calcitonin measurements in patients with apparently sporadic PHPT to exclude potential MEN 2 cases (70). Such a strategy in all PHPT patients or in PHPT patients with synchronous thyroid tumors found by ultrasonography would likely prove more cost effective than systematically carrying out RET mutation analysis. However, to our knowledge no evidence for or against this strategy exists.

\section{Conclusion}

Our data suggest that the prevalence of MEN 2A index cases that present with PHPT as their first manifestation is very low. The majority of index cases presenting with PHPT as first manifestation, have synchronous MTC, often node-positive. Thus, our observations suggest that not performing RET mutation analysis in patients with apparently sporadic PHPT would result in an extremely low false negative rate, if no other MEN 2A component, specifically MTC, are found during work-up or resection of PHPT.

\section{Supplementary materials}

This is linked to the online version of the paper at https://doi.org/10.1530/ EC-20-0163.

\section{Declaration of interest}

The authors declare that there is no conflict of interest that could be perceived as prejudicing the impartiality of the research reported.

\section{Funding}

S D received a national grant (AZV 16-32665A).

\section{Author contribution statement}

J $S$ Mathiesen conceived the study, drafted, revised and approved the manuscript. L $\mathrm{V}$ Larsen collected the data, revised and approved the manuscript. The remaining authors contributed data, critically revised and gave final approval of the manuscript.

\section{Acknowledgements}

A P would like to thank Dr Judit Toke, Prof. Dr Miklós Tóth, Prof. Dr Péter Igaz and Prof. Dr Károly Rácz (2nd Department of Medicine, Semmelweis University, Budapest, Hungary) for their help in collecting clinical data. T P $L$ thanks Dr Maran Olderode-Berends (Department of Medical Genetics, University Medical Center Groningen) for supporting the genetic data. B I A and V B would like to thank Prof. Murat Faik Erdoğan (Department of Endocrinology and Metabolism, Ankara University School of Medicine, Ankara, Turkey) and Prof. Jacques Azorin (Service de Chirurgie Thoracique et Vasculaire, Hôpital Avicenne, Bobigny, France), respectively. L V L, C G and J S M thank the Danish Thyroid Cancer Study Group (DATHYRCA) and the Danish MEN 2 group.

\section{References}

1 Donis-Keller H, Dou S, Chi D, Carlson KM, Toshima K, Lairmore TC, Howe JR, Moley JF, Goodfellow P \& Wells Jr SA. Mutations in the RET proto-oncogene are associated with MEN 2A and FMTC. Human Molecular Genetics 19932 851-856. (https://doi.org/10.1093/ $\mathrm{hmg} / 2.7 .851)$

2 Mulligan LM, Kwok JB, Healey CS, Elsdon MJ, Eng C, Gardner E, Love DR, Mole SE, Moore JK \& Papi L. Germ-line mutations of the RET proto-oncogene in multiple endocrine neoplasia type 2A. Nature 1993363 458-460. (https://doi.org/10.1038/363458a0)

3 Carlson KM, Dou S, Chi D, Scavarda N, Toshima K, Jackson CE, Wells Jr SA, Goodfellow PJ \& Donis-Keller H. Single missense mutation in the tyrosine kinase catalytic domain of the RET protooncogene is associated with multiple endocrine neoplasia type 2B. PNAS 199491 1579-1583. (https://doi.org/10.1073/pnas.91.4.1579)

4 Hofstra RM, Landsvater RM, Ceccherini I, Stulp RP, Stelwagen T, Luo Y, Pasini B, Hoppener JW, van Amstel HK \& Romeo G. A mutation in the RET proto-oncogene associated with multiple endocrine neoplasia type 2B and sporadic medullary thyroid carcinoma. Nature 1994367 375-376. (https://doi.org/10.1038/367375a0)

5 Eng C, Smith DP, Mulligan LM, Nagai MA, Healey CS, Ponder MA, Gardner E, Scheumann GF, Jackson CE \& Tunnacliffe A. Point mutation within the tyrosine kinase domain of the RET protooncogene in multiple endocrine neoplasia type $2 \mathrm{~B}$ and related sporadic tumours. Human Molecular Genetics 19943 237-241. (https://doi.org/10.1093/hmg/3.2.237)

6 Eng C, Clayton D, Schuffenecker I, Lenoir G, Cote G, Gagel RF, van Amstel HK, Lips CJ, Nishisho I, Takai SI, et al. The relationship between specific RET proto-oncogene mutations and disease phenotype in multiple endocrine neoplasia type 2 . International RET mutation consortium analysis. JAMA 1996276 1575-1579.

7 Opsahl EM, Brauckhoff M, Schlichting E, Helset K, Svartberg J, Brauckhoff K, Maehle L, Engebretsen LF, Sigstad E, Groholt KK, et al. A Nationwide study of multiple endocrine neoplasia type $2 \mathrm{~A}$ in Norway: predictive and prognostic factors for the clinical course of medullary thyroid carcinoma. Thyroid 201626 1225-1238. (https:// doi.org/10.1089/thy.2015.0673)

8 Mathiesen JS, Kroustrup JP, Vestergaard P, Stochholm K, Poulsen PL, Rasmussen ÅK, Feldt-Rasmussen U, Schytte S, Pedersen HB, Hahn CH, et al. Incidence and prevalence of multiple endocrine neoplasia $2 \mathrm{~A}$ in Denmark 1901-2014: a nationwide study. Clinical Epidemiology 2018 10 1479-1487. (https://doi.org/10.2147/CLEP.S174606)

9 Mathiesen JS, Kroustrup JP, Vestergaard P, Madsen M, Stochholm K, Poulsen PL, Krogh Rasmussen Å, Feldt-Rasmussen U, Schytte S, Pedersen $\mathrm{HB}$, et al. Incidence and prevalence of multiple endocrine neoplasia 2B in Denmark: a nationwide study. Endocrine-Related Cancer 201724 L39-L42. (https://doi.org/10.1530/ERC-17-0122)

10 Znaczko A, Donnelly DE \& Morrison PJ. Epidemiology, clinical features, and genetics of multiple endocrine neoplasia type $2 \mathrm{~B}$ in a complete population. Oncologist 201419 1284-1286. (https://doi. org/10.1634/theoncologist.2014-0277)

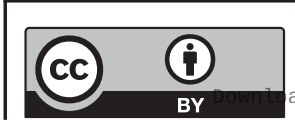

This work is licensed under a Creative Commons Attribution 4.0 International License. ded from Bioscientifica com at 04/26/2023 12:15:04PM 
11 Wells Jr SA, Asa SL, Dralle H, Elisei R, Evans DB, Gagel RF, Lee N, Machens A, Moley JF, Pacini F, et al. Revised American Thyroid Association guidelines for the management of medullary thyroid carcinoma. Thyroid 201525 567-610. (https://doi.org/10.1089/ thy.2014.0335)

12 Kloos RT, Eng C, Evans DB, Francis GL, Gagel RF, Gharib H, Moley JF Pacini F, Ringel MD, et al. Medullary thyroid cancer: management guidelines of the American Thyroid Association. Thyroid 200919 565-612. (https://doi.org/10.1089/thy.2008.0403)

13 Brandi ML, Gagel RF, Angeli A, Bilezikian JP, Beck-Peccoz P, Bordi C, Conte-Devolx B, Falchetti A, Gheri RG, Libroia A, et al. Guidelines for diagnosis and therapy of MEN type 1 and type 2. Journal of Clinical Endocrinology and Metabolism 200186 5658-5671. (https://doi. org/10.1210/jcem.86.12.8070)

14 Traugott AL \& Moley JF. Multiple endocrine neoplasia type 2: clinical manifestations and management. Cancer Treatment and Research 2010 153 321-337. (https://doi.org/10.1007/978-1-4419-0857-5_18)

15 Raue F, Kraimps JL, Dralle H, Cougard P, Proye C, Frilling A, Limbert E, Llenas LF \& Niederle B. Primary hyperparathyroidism in multiple endocrine neoplasia type 2A. Journal of Internal Medicine 1995238 369-373. (https://doi.org/10.1111/j.1365-2796.1995. tb01212.x)

16 Kraimps JL, Denizot A, Carnaille B, Henry JF, Proye C, Bacourt F, Sarfati E, Dupond JL, Maes B, Travagli JP, et al. Primary hyperparathyroidism in multiple endocrine neoplasia type IIa: retrospective French multicentric study. Groupe d'Etude des Tumeurs a Calcitonine. World Journal of Surgery 199620 808-812; discussion 812. (https://doi.org/10.1007/s002689900123)

17 Lebeault M, Pinson S, Guillaud-Bataille M, Gimenez-Roqueplo AP, Carrie A, Barbu V, Pigny P, Bezieau S, Rey JM, Delvincourt C, et al. Nationwide French study of RET variants detected from 2003 to 2013 suggests a possible influence of polymorphisms as modifiers. Thyroid 201727 1511-1522. (https://doi.org/10.1089/thy.2016.0399)

18 Imai T, Uchino S, Okamoto T, Suzuki S, Kosugi S, Kikumori T, Sakurai A \& MEN Consortium of Japan. High penetrance of pheochromocytoma in multiple endocrine neoplasia 2 caused by germ line RET codon 634 mutation in Japanese patients. European Journal of Endocrinology 2013168 683-687. (https://doi.org/10.1530/ EJE-12-1106)

19 Romei C, Mariotti S, Fugazzola L, Taccaliti A, Pacini F, Opocher G, Mian C, Castellano M, degli Uberti E, Ceccherini I, et al. Multiple endocrine neoplasia type 2 syndromes (MEN 2): results from the ItaMEN network analysis on the prevalence of different genotypes and phenotypes. European Journal of Endocrinology 2010163 301-308. (https://doi.org/10.1530/EJE-10-0333)

20 Maciel RMB, Camacho CP, Assumpcao LVM, Bufalo NE, Carvalho AL, de Carvalho GA, Castroneves LA, de Castro Jr FM, Ceolin L, Cerutti JM, et al. Genotype and phenotype landscape of MEN2 in 554 medullary thyroid cancer patients: the BrasMEN study. Endocrine Connections 20198 289-298. (https://doi.org/10.1530/EC-18-0506)

21 Mathiesen JS, Kroustrup JP, Vestergaard P, Stochholm K, Poulsen PL, Rasmussen ÅK, Feldt-Rasmussen U, Gaustadnes M, Orntoft TF, van Overeem Hansen T, et al. Distribution of RET mutations in multiple endocrine neoplasia 2 in Denmark 1994-2014: a Nationwide Study. Thyroid 201727 215-223. (https://doi.org/10.1089/thy.2016.0411)

22 Bergant D, Hocevar M, Besic N, Glavac D, Korosec B \& Caserman S. Hereditary medullary thyroid cancer in Slovenia - genotypephenotype correlations. Wiener Klinische Wochenschrift 2006118 411-416. (https://doi.org/10.1007/s00508-006-0636-8)

23 Patocs A, Klein I, Szilvasi A, Gergics P, Toth M, Valkusz Z, Forizs E, Igaz $\mathrm{P}, \mathrm{Al}$-Farhat $\mathrm{Y}$, Tordai A, et al. Genotype-phenotype correlations in Hungarian patients with hereditary medullary thyroid cancer. Wiener Klinische Wochenschrift 2006118 417-421. (https://doi. org/10.1007/s00508-006-0635-9)

24 Sharma BP \& Saranath D. RET gene mutations and polymorphisms in medullary thyroid carcinomas in Indian patients. Journal of
Biosciences 201136 603-611. (https://doi.org/10.1007/s12038-0119095-0)

25 Aydogan Bí, Yuksel B, Tuna MM, Navdar Basaran M, Akkurt Kocaeli A, Ertorer ME, Aydin K, Guldiken S, Simsek Y, Cihan Karaca Z, et al. Distribution of RET mutations and evaluation of treatment approaches in hereditary medullary thyroid carcinoma in turkey. Journal of Clinical Research in Pediatric Endocrinology 20168 13-20. (https://doi.org/10.4274/jcrpe.2219)

26 Diaz RE \& Wohllk N. Multiple endocrine neoplasia: the Chilean experience. Clinics 201267 (Supplement 1) 7-11. (https://doi. org/10.6061/clinics/2012(sup01)03)

27 Margraf RL, Crockett DK, Krautscheid PM, Seamons R, Calderon FR, Wittwer CT \& Mao R. Multiple endocrine neoplasia type 2 RET protooncogene database: repository of MEN2-associated RET sequence variation and reference for genotype/phenotype correlations. Human Mutation 200930 548-556. (https://doi.org/10.1002/humu.20928)

28 Mathiesen JS, Habra MA, Bassett JHD, Choudhury SM, Balasubramanian SP, Howlett TA, Robinson BG, GimenezRoqueplo AP, Castinetti F, Vestergaard P, et al. Risk profile of the RET A883F germline mutation: an international collaborative study. Journal of Clinical Endocrinology and Metabolism 2017102 2069-2074. (https://doi.org/10.1210/jc.2016-3640)

29 Castinetti F, Waguespack SG, Machens A, Uchino S, Hasse-Lazar K, Sanso G, Else T, Dvorakova S, Qi XP, Elisei R, et al. Natural history, treatment, and long-term follow up of patients with multiple endocrine neoplasia type 2B: an international, multicentre, retrospective study. Lancet: Diabetes and Endocrinology 20197 213-220. (https://doi.org/10.1016/S2213-8587(18)30336-X)

30 Khan AA, Hanley DA, Rizzoli R, Bollerslev J, Young JE, Rejnmark L, Thakker R, D'Amour P, Paul T, Van Uum S, et al. Primary hyperparathyroidism: review and recommendations on evaluation, diagnosis, and management. A Canadian and international consensus. Osteoporosis International 201728 1-19. (https://doi. org/10.1007/s00198-016-3716-2)

31 Edge SB, Byrd DR, Compton CC, Fritz AG, Greene FL \& Trotti A (eds). AJCC Cancer Staging Manual, 7th ed. New York, NY, USA: Springer, 2010.

32 Twigt BA, Scholten A, Valk GD, Rinkes IH \& Vriens MR. Differences between sporadic and MEN related primary hyperparathyroidism; clinical expression, preoperative workup, operative strategy and follow-up. Orphanet Journal of Rare Diseases 20138 50. (https://doi. org/10.1186/1750-1172-8-50)

33 Schuffenecker I, Virally-Monod M, Brohet R, Goldgar D, ConteDevolx B, Leclerc L, Chabre O, Boneu A, Caron J, Houdent C, et al. Risk and penetrance of primary hyperparathyroidism in multiple endocrine neoplasia type $2 \mathrm{~A}$ families with mutations at codon 634 of the RET proto-oncogene. Groupe D'etude des Tumeurs a Calcitonine. Journal of Clinical Endocrinology and Metabolism 199883 487-491. (https://doi.org/10.1210/jcem.83.2.4529)

34 Herfarth KK, Bartsch D, Doherty GM, Wells Jr SA \& Lairmore TC. Surgical management of hyperparathyroidism in patients with multiple endocrine neoplasia type 2A. Surgery 1996120 966-973; discussion 973-964. (https://doi.org/10.1016/s0039-6060(96)80042-0)

35 Howe JR, Norton JA \& Wells Jr SA. Prevalence of pheochromocytoma and hyperparathyroidism in multiple endocrine neoplasia type 2A: results of long-term follow-up. Surgery 1993114 1070-1077.

36 Frank-Raue K, Leidig-Bruckner G, Lorenz A, Rondot S, Haag C, Schulze E, Buchler M \& Raue F. Hereditary variants of primary hyperparathyroidism - MEN1, MEN2, HPT-JT, FHH, FIHPT. Deutsche Medizinische Wochenschrift 2011136 1889-1894. (https://doi. org/10.1055/s-0031-1286358)

37 Machens A \& Dralle H. Advances in risk-oriented surgery for multiple endocrine neoplasia type 2. Endocrine-Related Cancer 201825 T41-T52. (https://doi.org/10.1530/ERC-17-0202)

38 Sarika HL, Papathoma A, Garofalaki M, Saltiki K, Pappa T, PazaitouPanayiotou K, Anastasiou E \& Alevizaki M. Genetic screening of

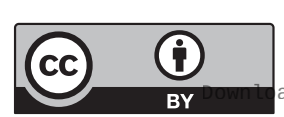

This work is licensed under a Creative Commons Attribution 4.0 International License. 
patients with medullary thyroid cancer in a referral center in Greece during the past two decades. European Journal of Endocrinology 2015 172 501-509. (https://doi.org/10.1530/EJE-14-0817)

39 Machens A, Lorenz K, Sekulla C, Hoppner W, Frank-Raue K, Raue F \& Dralle H. Molecular epidemiology of multiple endocrine neoplasia 2: implications for RET screening in the new millenium. European Journal of Endocrinology 2013168 307-314. (https://doi.org/10.1530/ EJE-12-0919)

40 Giacche M, Panarotto A, Tacchetti MC, Tosini R, Campana F, Mori L, Cappelli C, Pirola I, Lombardi D, Pezzola DC, et al. p.Ser891Ala RET gene mutations in medullary thyroid cancer: phenotypical and genealogical characterization of 28 apparently unrelated kindreds and founder effect uncovering in Northern Italy. Human Mutation 201940 926-937. (https://doi.org/10.1002/humu.23754)

41 Elisei R, Tacito A, Ramone T, Ciampi R, Bottici V, Cappagli V, Viola D, Matrone A, Lorusso L, Valerio L, et al. Twenty-five years experience on RET genetic screening on hereditary MTC: an update on the prevalence of germline RET mutations. Genes 201910 698. (https:// doi.org/10.3390/genes10090698)

42 Mathiesen JS, Kroustrup JP, Vestergaard P, Stochholm K, Poulsen PL, Rasmussen ÅK, Feldt-Rasmussen U, Gaustadnes M, Orntoft TF, Rossing M, et al. Founder effect of the RET(C611Y) mutation in multiple endocrine neoplasia 2A in Denmark: a nationwide study. Thyroid 201727 1505-1510. (https://doi.org/10.1089/thy.2017.0404)

43 Cunha LL, Lindsey SC, Franca MIC, Sarika L, Papathoma A, Kunii IS, Cerutti JM, Dias-da-Silva MR, Alevizaki M \& Maciel RMB. Evidence for the founder effect of RET533 as the common Greek and Brazilian ancestor spreading multiple endocrine neoplasia 2A. European Journal of Endocrinology 2017176 515-519. (https://doi.org/10.1530/EJE-161021)

44 Martins-Costa MC, Cunha LL, Lindsey SC, Camacho CP, Dotto RP, Furuzawa GK, Sousa MS, Kasamatsu TS, Kunii IS, Martins MM, et al. M918V RET mutation causes familial medullary thyroid carcinoma: study of 8 affected kindreds. Endocrine-Related Cancer 201623 909-920. (https://doi.org/10.1530/ERC-16-0141)

45 Machens A, Lorenz K, Weber F \& Dralle H. Geographic epidemiology of MTC families: unearthing European ancestral heritage. Endocrine-Related Cancer 201825 L27-L30. (https://doi.org/10.1530/ERC-17-0514)

46 Machens A, Lorenz K \& Dralle H. Peak incidence of pheochromocytoma and primary hyperparathyroidism in multiple endocrine neoplasia 2: need for age-adjusted biochemical screening. Journal of Clinical Endocrinology and Metabolism 201398 E336-E345. (https://doi.org/10.1210/jc.2012-3192)

47 Raue F, Bruckner T \& Frank-Raue K. Long-term outcomes and aggressiveness of hereditary medullary thyroid carcinoma: 40 years of experience at one center. Journal of Clinical Endocrinology and Metabolism 2019104 4264-4272. (https://doi.org/10.1210/jc.201900516)

48 Machens A, Lorenz K, Weber F \& Dralle H. Genotype-specific progression of hereditary medullary thyroid cancer. Human Mutation 201839 860-869. (https://doi.org/10.1002/humu.23430)

49 Mathiesen JS, Kroustrup JP, Vestergaard P, Stochholm K, Poulsen PL, Rasmussen ÅK, Feldt-Rasmussen U, Schytte S, Londero SC, Pedersen HB, et al. Survival and long-term biochemical cure in medullary thyroid carcinoma in Denmark 1997-2014: a nationwide study. Thyroid 201929 368-377. (https://doi.org/10.1089/thy.2018.0564)

50 Machens A \& Dralle H. Surgical treatment of medullary thyroid cancer. Recent Results in Cancer Research 2015 204 187-205. (https:// doi.org/10.1007/978-3-319-22542-5 9)

51 Censi S, Cavedon E, Watutantrige-Fernando S, Barollo S, Bertazza L, Manso J, Iacobone M, Nacamulli D, Galuppini F, Pennelli G, et al. Unique case of a large indolent medullary thyroid carcinoma: time to reconsider the medullary thyroid adenoma entity? European Thyroid Journal 20198 108-112. (https://doi.org/10.1159/000494675)

52 Opsahl EM, Akslen LA, Schlichting E, Aas T, Brauckhoff K, Hagen AI, Rosenlund AF, Sigstad E, Groholt KK, Jorgensen LH, et al. The role of calcitonin in predicting the extent of surgery in medullary thyroid carcinoma: a nationwide population-based study in Norway. European Thyroid Journal 20198 159-166. (https://doi. org/10.1159/000499018)

53 Schuffenecker I, Ginet N, Goldgar D, Eng C, Chambe B, Boneu A, Houdent C, Pallo D, Schlumberger M, Thivolet C, et al. Prevalence and parental origin of de novo RET mutations in multiple endocrine neoplasia type $2 \mathrm{~A}$ and familial medullary thyroid carcinoma. Le Groupe d'Etude des Tumeurs a Calcitonine. American Journal of Human Genetics 199760 233-237.

54 Castinetti F, Maia AL, Peczkowska M, Barontini M, Hasse-Lazar K, Links TP, Toledo RA, Dvorakova S, Mian C, Bugalho MJ, et al. The penetrance of MEN2 pheochromocytoma is not only determined by RET mutations. Endocrine-Related Cancer 201724 L63-L67. (https:// doi.org/10.1530/ERC-17-0189)

55 Frank-Raue K, Rybicki LA, Erlic Z, Schweizer H, Winter A, Milos I, Toledo SP, Toledo RA, Tavares MR, Alevizaki M, et al. Risk profiles and penetrance estimations in multiple endocrine neoplasia type 2A caused by germline RET mutations located in exon 10. Human Mutation 201132 51-58. (https://doi.org/10.1002/humu.21385)

56 Milos IN, Frank-Raue K, Wohllk N, Maia AL, Pusiol E, Patocs A, Robledo M, Biarnes J, Barontini M, Links TP, et al. Age-related neoplastic risk profiles and penetrance estimations in multiple endocrine neoplasia type 2A caused by germ line RET Cys634Trp (TGC>TGG) mutation. Endocrine-Related Cancer 200815 1035-1041. (https://doi.org/10.1677/ERC-08-0105)

57 Machens A, Niccoli-Sire P, Hoegel J, Frank-Raue K, van Vroonhoven TJ, Roeher HD, Wahl RA, Lamesch P, Raue F, ConteDevolx B, et al. Early malignant progression of hereditary medullary thyroid cancer. New England Journal of Medicine 2003349 1517-1525. (https://doi.org/10.1056/NEJMoa012915)

58 Eng C, Mulligan LM, Smith DP, Healey CS, Frilling A, Raue F, Neumann HP, Ponder MA \& Ponder BA. Low frequency of germline mutations in the RET proto-oncogene in patients with apparently sporadic medullary thyroid carcinoma. Clinical Endocrinology 199543 123-127. (https://doi.org/10.1111/j.1365-2265.1995.tb01903.x)

59 Modigliani E, Vasen HM, Raue K, Dralle H, Frilling A, Gheri RG, Brandi ML, Limbert E, Niederle B \& Forgas L. Pheochromocytoma in multiple endocrine neoplasia type 2: European study. The Euromen Study Group. Journal of Internal Medicine 1995238 363-367. (https:// doi.org/10.1111/j.1365-2796.1995.tb01211.x)

60 Mulligan LM, Marsh DJ, Robinson BG, Schuffenecker I, Zedenius J, Lips CJ, Gagel RF, Takai SI, Noll WW \& Fink M. Genotype-phenotype correlation in multiple endocrine neoplasia type 2 : report of the International RET Mutation Consortium. Journal of Internal Medicine 1995238 343-346. (https://doi.org/10.1111/j.1365-2796.1995. tb01208.x)

61 Mulligan LM, Eng C, Healey CS, Clayton D, Kwok JB, Gardner E, Ponder MA, Frilling A, Jackson CE \& Lehnert H. Specific mutations of the RET proto-oncogene are related to disease phenotype in MEN 2A and FMTC. Nature Genetics 19946 70-74. (https://doi.org/10.1038/ ng0194-70)

62 Mulligan LM, Eng C, Attie T, Lyonnet S, Marsh DJ, Hyland VJ, Robinson BG, Frilling A, Verellen-Dumoulin C \& Safar A. Diverse phenotypes associated with exon 10 mutations of the RET protooncogene. Human Molecular Genetics 19943 2163-2167. (https://doi. org/10.1093/hmg/3.12.2163)

63 Castinetti F, Qi XP, Walz MK, Maia AL, Sanso G, Peczkowska M, HasseLazar K, Links TP, Dvorakova S, Toledo RA, et al. Outcomes of adrenalsparing surgery or total adrenalectomy in phaeochromocytoma associated with multiple endocrine neoplasia type 2: an international retrospective population-based study. Lancet: Oncology 201415 648-655. (https://doi.org/10.1016/S1470-2045(14)70154-8)

64 Bilezikian JP, Bandeira L, Khan A \& Cusano NE. Hyperparathyroidism. Lancet 2018391 168-178. (https://doi. org/10.1016/S0140-6736(17)31430-7)

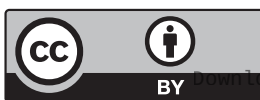

This work is licensed under a Creative Commons Attribution 4.0 International License. ded from Bioscientifica.com at 04/26/2023 12:15:04PM 
65 Verbeek HH, de Groot JWB, Sluiter WJ, Muller Kobold AC, van den Heuvel ER, Plukker JT \& Links TP. Calcitonin testing for detection of medullary thyroid cancer in people with thyroid nodules. Cochrane Database of Systematic Reviews 20203 CD010159. (https://doi. org/10.1002/14651858.CD010159.pub2)

66 Opsahl EM, Akslen LA, Schlichting E, Aas T, Brauckhoff K, Hagen AI, Rosenlund AF, Sigstad E, Groholt KK, Maehle L, et al. Trends in diagnostics, surgical treatment, and prognostic factors for outcomes in medullary thyroid carcinoma in Norway: a nationwide population-based study. European Thyroid Journal 20198 31-40. (https://doi.org/10.1159/000493977)

67 Machens A \& Dralle H. Surgical cure rates of sporadic medullary thyroid cancer in the era of calcitonin screening. European Journal of Endocrinology 2016175 219-228. (https://doi.org/10.1530/EJE-160325)
68 Saltiki K, Rentziou G, Stamatelopoulos K, Georgiopoulos G, Stavrianos C, Lambrinoudaki E \& Alevizaki M. Small medullary thyroid carcinoma: post-operative calcitonin rather than tumour size predicts disease persistence and progression. European Journal of Endocrinology 2014171 117-126. (https://doi.org/10.1530/EJE-14-0076)

69 Elisei R \& Romei C. Calcitonin estimation in patients with nodular goiter and its significance for early detection of MTC: European comments to the guidelines of the American Thyroid Association. Thyroid Research 20136 (Supplement 1) S2. (https://doi. org/10.1186/1756-6614-6-S1-S2)

70 Skandarajah A, Barlier A, Morlet-Barlat N, Sebag F, Enjalbert A, Conte-Devolx B \& Henry JF. Should routine analysis of the MEN1 gene be performed in all patients with primary hyperparathyroidism under 40 years of age? World Journal of Surgery 201034 1294-1298. (https://doi.org/10.1007/s00268-009-0388-5)

Received in final form 16 April 2020

Accepted 6 May 2020

Accepted Manuscript published online 6 May 2020

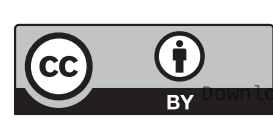

This work is licensed under a Creative Commons Attribution 4.0 International License.

ded from Bioscientifica.com at 04/26/2023 12:15:04PM 